\title{
ДИДЖИТАЛИЗАЦИЯ НОТАРИАТОВ ЕВРОПЕЙСКОГО СОЮЗА: НОВЫЕ РЕАЛИИ И ПЕРСПЕКТИВЫ РАЗВИТИЯ (НА ПРИМЕРЕ ФРАНЦИИ)
}

\section{DIGITALIZATION OF EUROPEAN UNION NOTARIES: NEW REALITIES AND DEVELOPMENT PROSPECTS (ON THE EXAMPLE OF FRANCE)}

\section{Z. Tarasenko}

Summary. The article analyzes the process of digitalization of the legal system of the European Union with an emphasis on notarial procedures related to the provision of justice in European legal institutions. The problems arising during the so-called 'digitization' of legal mechanisms are highlighted. The experience of France is taken as an example of the introduction of innovative IT solutions in the field of notary (casestudy).

Keywords: notary, digital notary, European Union, digitalization of law.

B течение 2020 года европейским гражданам пришлось радикально перестроить свою жизнь в соответствии с новой реальностью, вызванной пандемией коронавируса. По большей части это означало быструю «миграцию» их личной и профессиональной жизни в Интернет-сферу.

В судебном мире это создало ряд проблем, но также и возможностей. Со своей стороны, нотариусам по всему Европейском Союзу пришлось быстро адаптироваться к этому новому контексту. Официальный Брюссель достаточно оперативно отреагировал на новые реалии: Европейская Комиссия опубликовала официальную «Стратегию цифровизации правосудия», направленную на поддержку и содействие внедрению цифровых инструментов на всех уровнях судебной системы.

Нотариальные службы со всего объединения заявили, что EC должен обратить внимание на то, какие глобальные субъекты имеют «контроль и доступ» к ключевым технологиям, используемым в судебных процессах
Тарасенко Зоя Анатольевна

Аспирант, ФГАОУ ВО «Российский Университет Транспорта» (РУТ (МИИТ), г. Москва zoya.tarasenko@gmail.com

Аннотация. В статье анализируется процесс диджитализации правовой системы Европейского Союза с акцентированием внимания на нотариальных процедурах, связанных с обеспечением правосудия в европейских правовых институтах. Выделяются проблемы, возникающие при так называемой «оцифровке» правовых механизмов. В качестве примера внедрения инновационных ИТ-решений в сфере нотариата взят опыт Франции (кейс).

Ключевые слова: нотариат, цифровой нотариат, Европейский союз, диджитализация права.

в рамках продолжающейся цифровизации правового сектора.

Этот призыв прозвучал после того, как Европейская комиссия представила свое видение о цифровизации правосудия в ЕС, направленное на содействие более широкому использованию цифровых инструментов в секторе и облегчение доступа к информации в трансграничных делах.

И хотя профессионалы в этой области приветствовали приверженность продвижению цифровизации в судебных делах, Комиссии следует также рассмотреть меры, которые могли бы еще больше гарантировать юридическим службам и гражданам, что конфиденциальные данные, обрабатываемые с использованием технологий следующего поколения, должным образом защищены.

Представляется, что суть проблемы заключается не сколько в природе процесса цифровизации права, сколько в обеспечении защищенного доступа и кон- 
троля над этим процессом. В процессе быстрой оцифровки нотариальных услуг существует ряд неотложных вопросов, которые необходимо решать в будущем, в том числе о том, как ЕС может обеспечить защиту конфиденциальных данных и независимость судебной власти в использовании ИТ-систем [6; 7].

Примечательно, что в мае-июне 2020 года состоялось Специальное заседание Объединения Нотариусов Европы (в организацию входят нотариусы из 22 стран EC), на котором были выделены две ключевые проблемы, с которыми столкнуться профильные специалисты при осуществлении более масштабной цифровизации европейского права:

1. Как можно обеспечить безболезненную интеграцию искусственного интеллекта и механизмов человеческого контроля [1]?

2. Как можно избежать исключения пожилых людей или людей с ограниченными возможностями из процесса цифровизации и не усилить цифровой разрыв, который уже существует среди европейского населения?

3. Каким образом можно достичь европейского цифрового суверенитета в нотариальной отрасли [5], собственно, как и в остальных отраслях европейского права?

Последняя вышеупомянутая проблема стала еще более актуальной в связи с принятием в США «Закона об облачном хранении», который фактически направлен на то, чтобы заставить поставщиков ИТ-услуг передавать данные ЕС американским профильным службам. «Закон об облачном хранении», в частности, предоставляет правоохранительным органам США официальное право принудительно разглашать данные клиентов за пределами США, что приводит к «экстерриториальному охвату полномочий».

По нашему мнению и по мнению большинства европейских юристов, американский «Закон об облачном хранении» может поставить под угрозу контроль Европы над конфиденциальными данными и владение ключевыми технологиями, используемыми для обработки таких данных.

Цифровизация европейской правовой системы набирает обороты: европейскими нотариусами были тепло встречены обновленные планы Еврокомиссии по содействию внедрению цифровых инструментов в судебном секторе, в частности, для упрощения трансграничного обмена доказательствами, необходимыми для дел с участием нескольких государств-членов ЕС.

Более того, была принята Европейская судебная Стратегия подготовки кадров на 2021-2024 годы, что расширяет сферу обучения европейском праву (в программу подготовки вошли новые дисциплины, такие как «цифровизация права», «искусственный интеллект и право»).

С ноября 2021 года благодаря усилиям Объединения Нотариусов Европы будет запущена принципиально новая учебная программа, подразумевающая создание онлайн-обучающей платформы для нотариусов EC, которая в конечном итоге будет включать все области законодательства ЕС, представляющие интерес для нотариальной профессии.

Стоит отметить, что в период разгара пандемии COVID-19 нотариальные услуги [2; 3] были вынуждены радикально адаптироваться к формату удаленной работы в условиях жестких эпидемиологических ограничений.

Удаленная аутентификация, электронное архивирование, междугородние видеоконференции и электронная проверка личности стали повседневными элементами европейских нотариусов.

К концу 2021 года Еврокомиссия представит законопроект, основанный на процедурах трансграничного судебного сотрудничества по гражданским, коммерческим и уголовным делам.

В 2021 году уже был поддержан проект закона об обмене цифровой информацией по делам о трансграничном терроризме, были сформированы соответствующие планы совместного расследования.

Что касается трансграничных судебных дел, то система управления делами «Евроюст» будет обновлена, чтобы способствовать улучшению сотрудничества между национальными органами в отношении преступлений, связанных с многонациональным элементом. Кроме того, Еврокомиссия стремится улучшить использование электронной системы e-Codex (дословно - «электронный кодекс») - основного инструмента для безопасного сотрудничества в гражданском, коммерческом и уголовном судопроизводстве через границы - во всех государствах-членах EC.

Необходимо понимать, что цифровизация правосудия теперь не просто приятная «вещь» или «услуг», которую нужно иметь, она стала крайней необходимостью [4]. Юристы и юридические службы (включая институт нотариусов) являются неотъемлемой частью правового порядка, и поэтому необходимость их участия в процессе цифровой трансформации логична аи неоспорима. 
Далее обратимся к опыту Франции и рассмотрим как французские специалисты внедряют ИТ-технологии в нотариальные услуги и в целом в национальную систему правосудия.

Хотелось бы начать с того, что процесс диджитализации французского нотариата была запущен еще в начале 2000-х гг. Институт нотариата во Франции имеет защищенную частную сеть, базирующуюся на современных передовых технологиях. В сотрудничестве с профильными государственными службами французский нотариат создал несколько цифровых инструментов, которые позволяют нотариусам исполнять свои функции более быстро и при соблюдении высокого уровня безопасности.

В частности, начиная с 2000 года институт нотариата во Франции создал специальную онлайн-платформу для осуществления информационного обмена между французскими нотариатами и их партнерами в лице Министерства экономики и финансов, Министерства правосудия и банков. Платформа получила название «Планета» (от французского слова 'planete').

На базе данной платформы Генеральным Директоратом государственных финансов Министерства экономики и финансов Франции был разработан Протокол обмена, целью которого является обеспечение системы функционирования земельных кадастров. Протокол получил название «Телеакты» и позволяет напрямую в онлайн режиме запросить выписку из базы земельного кадастра, а также регистрацию заявлений на оформление объектов недвижимости.

К началу 2018 года все коммуникации между нотариальными конторами и службами земельного администрирования Франции полностью переведены в цифровой формат. Ежегодно на базе «Телеакты» проводятся до 7 млн. консультаций и регистрационных процедур [4]. Данный протокол фактически выполняет роль электронной платформы, совмещающей публикацию аутентичных (подлинных) правовых документов и оплату соответствующих налогов и сборов в единую операцию. Тем самым, во Франции нотариаты стали эффективными крупнейшими сборщиками налогов наравне с государством, поэтому перевод всех обменов и, в частности, финансовых операций в цифровой формат был обоснован и крайне важен для функционирования всей правовой системы Франции.
В настоящее время институт нотариата во Франции активно работает в тандеме с государством над внедрением практики прямых консультаций по ведению кадастра недвижимости, которые будут осуществляться нотариусами, собственно, как и непосредственная регистрация ими сделок по купле-продаже недвижимости в онлайн-режиме.

В 2008 году Нотариаты Эльзаса и Мозелля совместно с Министерством правосудия ввели систему e-rin - cистему подачи электронных запросов на учет земельных участков. Тем самым, появился прецедент, когда учёт и обработка запросов в кадастровом реестре были полностью переведены в цифровой формат.

Закон Франции № 2000-230 от 13 марта 2000 года был направлен на адаптацию и подтверждение легитимности применения ИТ-технологий и цифровой подписи во французской правовой системе. Таким образом, был закреплен принцип правовой равнозначности между правовыми актами на бумажном носителе и электронными документами, что также отразилось и на применении общих требований безопасности к документам обоих форматов.

10 августа 2005 года в Декрете № 973-2005 были законодательно закреплены условия по созданию и хранению правовых документов, подлинность которых была заверена нотариусами в электронном формате. Нотариат Франции внедрил данные требования для всех французских регионов, и в результате 28 октября 2008 года стало отправной точкой для всеобщего функционирования электронных нотариатов во Франции: официально был подписан первый правовой документ, заверенный электронно.

Наконец, для нашей страны важно почерпнуть опыт Франции в создании электронных архивов MICEN, которые позволяют хранить электронно заверенные нотариусом документы в течение 75 лет. К 2019 году в системе MICEN было зарегистрировано 10 млн. аутентичных документов.

Также перспективным представляется сотрудничество французских и российских нотариатов в сфере внедрения практики блокчейн-технологий. С 2019 года Нотариат Франции запустил в формате старт-апа прототип блокчейн-технологии для заверения копий документов, подлежащих к исполнению. Данная технология тестируется совместно с банками.

1. Дроздова Е.А. ІТ-технологии в работе нотариата // Нотариус. 2020. № 2.

\section{ЛИТЕРАТУРА}

2. Основы законодательства Российской Федерации о нотариате (утв. ВС РФ 11.02.1993 N4462-1) (ред. от 03.07.2016). 
3. Проект федерального закона № 750699-7 «0 внесении изменений в Основы законодательства Российской Федерации о нотариате и отдельные законодательные акты Российской Федерации» (внесен 10.07.2019 Правительством Российской Федерации) // URL: https://sozd.duma.gov.ru/bill/750699_ 7\#bh_hron

4. Тымчук Ю.А. Нотариальное удостоверение сделок с недвижимостью двумя и более нотариусами: преимущества и перспективы // Нотариус. 2020. № 4.

5. Углицких Д.В. К вопросу «электронного нотариата»: правовые аспекты регулирования и проблемы практики // Нотариус. 2020. № 3.

6. Шаповалова Л.Л. Институт нотариата в России: историко-правовой аспект. Ставрополь, 2000.

7. Merryman J. (1985) The Civil Law Tradition. — 2d ed.

8. Ordonnance № $45-2590$ du 2 Novembre 1945 relative au Statut du Notariat

() Тарасенко Зоя Анатольевна ( zoya.tarasenko@gmail.com ).

Журнал «Современная наука: актуальные проблемы теории и практики»

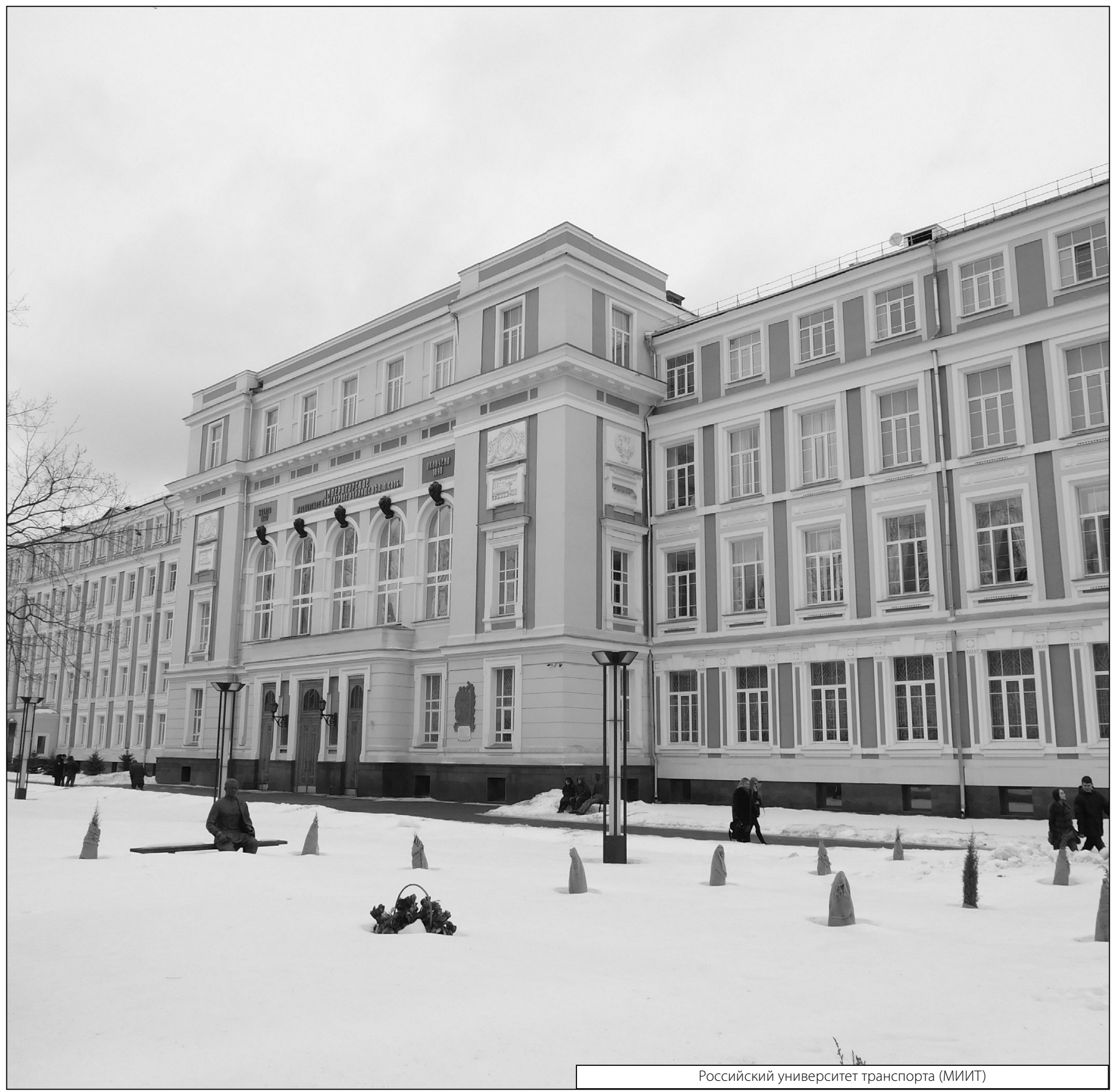

